\title{
Digital Revolution and the Renewed Mechanism of Religious Discourse
}

\author{
A Z Baharuddin \\ Sekolah Tinggi Agama Islam Negeri (STAIN) Majene, \\ Jalan Balai Latihan Kerja, Totoli, Banggae, Majene 91415, Sulawesi Barat ${ }^{1}$ \\ $\left\{\right.$ andizamakhsyari@stainmajene.co.id $\left.^{1}\right\}$
}

\begin{abstract}
The digital age is a witness of the world's inventions of modern technology devices and digital applications that have changed the concept of time and place. The data age has imposed a numerous patterns of behavior and attitudes. In the light of the data age, religious discourse should be performed to keep in alignment with these technological developments in order to and take benefits from them. Scientists have been talking about the needs for the renewal of religious discourse in terms of forms, methods, and means in which its horizons are expanded to keep pace with progress and excellence and are presented in the best mannner and the clearest way. Islam is no exception. Its universality requires a renewed form or mechanism of religious discourse in this digital age. This article is to describe the needs for taking the benefits from the the tools and methods in the digital data age leading to the renewal of religious discourse mechanism. The author is using an analytical and an inductive method based on some studies on this subject through different opinions and ideas. It found that communication and information technologies of the digital age may serve the best tools for the renewal of religious discourse in dakwah.
\end{abstract}

Keywords: Digital Revolution, Mechanism, Renewal of Religious Discourse

\section{Introduction}

The renewal of Islamic thoughts, as a matter of principle, represents the problem and the solution together. It is a problem because no one wants to start doing it, and it is a solution because there is no alternative way to get rid of the intellectual crisis in the Islamic world. The renewal process is not an easy process. It is a complicated matter because it involves a religious collision with the mundane in which two opposites exist, i.e. the religious for its rigidity and stagnation, and the mundane for its vitality and dynamism. In other words, religious thoughts are biased to the past, while the renewal seeks to transfer the present into positive interaction and humans oriented thoughts [1].

The term 'renewal' is not a new invention in religion for it is a natural perspective dictated by religious texts and the evolution of life to achieve its validity for any time and place, and its flexibility for the development and acceptance of new developments with preserving the constants that ensure its survival over the age. Thus, "the renewal" is not the antithesis of "religion", rather it is the way how religion and its basic elements and assets are transferred into the new fields and things for its survival in every time and place[2]. 
The world has witnessed developments and terrible changes in all areas. It is natural that religious discourse is adjusting to the circumstances of each era by constantly renewing its discourse styles and contents. It is only by doing so that religious messages can reach the people's minds and hearts. If religion is separated from the reality of life and the variables of age, it would not attract attention[3].

The renewal of religious discourse, although it seemed to be new, has been applied since a long time ago, and the call to do it always repeats every time. The roots and the call for it can be traced back to the end of Ottoman Empire. The renewal does not mean compromising the essence of faith or constants of the Islamic principles and values. It refers to the renewed tools and means of communication and interaction between the preacher and his audience[4].

There is no doubt that religious discourse needs to be renewed in order to keep pace with the changing reality of people and their conditions as well as with new methods of life through which components and contents of the speech are delivered[5]. This is particularly the case in the era of modern technology, information revolution, and communication. If a discourse in a traditional pattern is followed everywhere and in every circumstance despite the changing circumstance, place, and human beings, it would become obsolete and, therefore, needs to be refined and re-drafted.

In Islamic or Muslim countries, dakwa requires us to overcome and eliminate all the challenges for which there is a need for renewing and modernizing traditional tactics and new mechanisms to catch up with technical and technological progress. It is especially true in the areas of information and communication. Provided that Muslims are utilizing this technology in favor of dakwa, it will become a great and useful asset for Islamic dakwa.

The digital revolution is a fundamental shift in the nature of contemporary life, especially with regard to the aspects of communication, dialogue and cultural interaction between communities and people. How we adapt to the digital revolution in its various manifestations has generated a number of questions, such as how is the relationship between the revolution in digital data and the reality of human communication and then what are the impacts on dakwa communication? This revolution has expanded the potential of dakwa by reducing differences in time, place and language and overcoming the barriers of time, distance, and cultural as well as linguistic expertise. In addition, technology has connected peoples wherever they are through a single connection based on communication and information networks[6].

These technological means have opened a wide door for spreading the dakwa discourse both for Muslims and non-Muslims. They serve as guidance and awareness for Muslims to eliminate the lust and fight the evil, and a channel to inform and teach Islam to non-Muslims. Therefore, Muslim preachers should exploit scientific and technological development and take the benefits from the modern tools according to what serves the best for the dakwa discourse. Based on this background, this study seeks to examine the needs for the renewal of religious discourse mechanisms in accordance with the current development in order to increase the level of impacts.

\section{Method}

Based on the subject and the objectives of the study, the author used a descriptiveanalytical approach. This study aims to understand the phenomenon being studied for which the data is collected and analyzed so that an accurate explanation about the phenomenon can be obtained. The author depended on library resources relevant to the topics, such as books, magazines, newsletters, articles, and scientific journals. The study seeks to identify the current 
developments in the digital revolution and its relation to the necessary adjustment mechanism of religious discourse.

\section{Result and Discussion}

\section{Islamic Rhetoric (Vision for the Future)}

The future of Islamic rhetoric is not different from that of the Islamic world, which is to develop as far as possible Muslim societies. For this purpose, Islamic rhetoric is renewed to the extent it goes in line with changes. However, the reality of Islamic structure does not develop well since modernity in Islamic world is imported. The prevailing Islamic rhetoric does not attribute the contemporary status, and even if it started from the heritage, it is a contemporary form in the framework and heritage in its content[7].

Researchers who recorded the phenomenon and analyzed religious discourse found the mismatch between the original and the contemporary. When the means of communication develop professionally and technically due to the information revolution and progress in the production of modern media, this progress is not accompanied by a parallel development in the renewal of the mechanism and content of Islamic discourse in the context of adhering to the constants, good understanding of contemporary changes and deal with them in order to achieve the desired objectives[8].

Islam does not reject the global reality and, therefore, it is required to adapt to globalization in order to position Islam in the framework of joint action, to have the conditions to adapt to life changes. This is so because the reality is now different from the earlier era where Muslims lived in. All we can say that we appreciate our old scientists for their knowledge legacy. However, the great values of their jurisprudence should not be taken for granted. In fact, most of them have been said and applied in the past that was not our time. We possess the weapon of knowledge, enough for us in what has been achieved in the development of our reality and the emergence of new methods of research makes us reconsider what was on the table before.

The renewal is a development and is not an old recovery. But, conversion to the new is not either by taking from the old or diligence in the new extraction[9]. It requires us to take another step that will correct the course taken by our good predecessor by working on the appropriate consistent with the requirements of both religious discourse and reality. Islamic discourse should stick to its Islamic characters and consistent with the reality in order to avoid the denial of the realities of creation and composition. The process is not a combination of what is known today as heritage and modernity, or originality and contemporary. Religious discourse is not heritage. Most of its components and the reality can not be once confined to the narrow modernity[10].

The Islamic discourse is the organization of relationships between human beings with their Creator, with each other, and with the universe in which they are living in and drawing from its bounty. All these pushed people towards progress and development, allowing them to consider it and discover its hidden treasures, and to live according to the divine laws, urging them to recognize it and use it in a way that brings goodness and happiness to people[11].

\section{The Digital Age and Society}

The development and growth of human societies in the global arena and in various fields are interesting to be studied. The pace of development has become successive, calling for a thorough understanding of the reality in order to grasp the future requirements. Digital 
technology may turn around tangles with daily life, and then this transformation leads to innovation and new applications that come into contact with our daily lives in different ways. Whereas, there are a lot of opportunities and aspirations associated with digitization and there is also a basic need to understand and mitigate the challenges posed for society[12].

This era is the information age, where information became accessible to all of us. It is a mechanical society with unique characteristics of strong thinking and automated communication through an innovative mechanism. The individual and society are forced to acquire the skills that enable them to adapt their thinking and ways of life[13]. It is a social network for a group of individuals who are interacting with each other through a means of modern communication and social sites [14].

The "digital society" is not coming from a vacuum. It has been going through the stages of transformation, one of which the stages of transformation of the human society in general, and these previous shifts to the human society came one stage after another, there is single ascending line represents of these shifts and links the transition of the human society from primitive society to the farming community, and then to an industrial society, and finally a digital society, and who knows what will be the transformation of the human society in the long run over. It launched this community several other names similar language and consistent semantics exclusively: "digital wrapper", and "Digital Society", and "Information Society" and "Knowledge Society", and "E-Society", and "Paperless Society", and "Networked society", and "Post-industrial society", and "Post-modern society", and "Global society"[15].

The transformation of traditional society into a digital society requires a number of necessary steps and appropriate procedures, including the strengthening of the ability of society to recognize this shift in a way that does not adversely affect society's values and cultural identity, social and religious, and here are summarized these steps:[16]

1. Infrastructure preparation creates a digital community of technology, and communication networks and the media to be well suited to deal with modern technology and mechanisms.

2. The use of modern systems and using them in access to information and maintain it.

3. Encourage the use of modern technology in various fields of life, and support it through to the spread of technology in a constructive manner.

4. Put correct foundations for research and development in this area taking full support for the scientific base depends on building a digital society.

5. Internally and externally organizing efforts with a clear policy to move to a digital society through to the objectives set.

6. Dissemination of digital awareness in levels of life using effective media in achieving this goal.

7. Adding informatics knowledge in school curricula and linking practical aspects of life with continued commitment to modernize its mechanisms.

8. Taking into account the characteristics of the national, religious and national identity of the community.

9. The smooth of the transformation process and methodology, by the way, do not cause an exit from its goals setting.

\section{Globalized Islamic Rhetoric}

We mean by this title of the religious discourse that transcends the limits of time and place and has an impact on the world through what is owned and what is available from the argument of its potential. The realization of the globalization discourse to ensure compatibility between the discourse and the current reality, with all its social, intellectual and other 
dimensions requires a great deal of attention to the most important things: the development of religious discourse forms and content mechanisms[17].

Religious discourse emanates from Islam of Qur'an and the Sunnah, not Islam certain era imposes itself on our time, it is discourse that corresponds to his time and place, with the development of its shape by using modern means, so have developed a calculated impact and results, thanks to the technology revolution, it has become the religious discourse locked into certain forms of old methods of communication, it did not develop in the mechanisms of only a modicum limited.

This attempt aimed at the progressive development of mechanisms of religious discourse does not mean the abolition of traditional forms of rhetorical speeches and lessons despite their importance. If we go back to the era of the Prophet, peace be upon him we found that, despite the simplicity and ease of the means harnessed at that time, but he chose the best as it is a kind in the methods in order to achieve the call to God, then diversity in the media, especially at the time of discourse crisis, according to the requirements and conditions of each era is such as creativity and methods the Prophet[5].

If we consider in the current religious discourse we will find that, despite the stunning development of the means of technology but it is still characterized by shortening, which leads us to the need to modernize our Islamic speeches methods and review them to correct concepts. The development of discourse mechanisms is the process of the new addition of on the old without demolition or void, but adds the new needed by the times, and its position on the old based on the idea of duty time, and so the former had fulfilled their time duty on the basis of their life and time and had achieved successes, and each era has a duty different from the duty of previous eras, and therefore, with all respect for the knowledge legacy, we stand up for the future against stagnant, and we respect it and add to it and re-formulate its mechanisms in a manner consistent with the new ones we have added it[18].

\section{A Proposal to Renew the Form of Religious Discourse Mechanisms}

The religious discourse stems from the religious vision as a reference, and then it is the medium between the Koran and the Sunna, which describes Islam and the provisions, it is a way and approach in thinking and perception and to express ideas and perceptions, it is natural in light of the development of science in the world to develop our vision of religion and our understanding of the texts, and we do not want to distort the truth or texts and disregard them or put them always in the passive position. The religious consciousness despite centuries of scientific progress was undeveloped because of our failure to keep pace with it, therefore it was necessary for us to take into account the evolution of knowledge to carry out a new reading, to give it more vitality and freshness[19].

It's well known that in light of the increasing pace of technology smart people have benefited it in various areas of life, however, the roles of this digital revolution have not been matched by a corresponding development in the mechanisms of its use of preaching or dawa only in a limited framework despite its considerable influence in shaping public opinion. Hence, the renewal form and mechanisms and the presentation of religious discourse at least, important as the renewal of the contents of this discourse, because the correct religious discourse and influential is the community safety valve[20]. Among the most important developments that have been added to the mechanisms of religious discourse is the introduction of theater and cinema arts in the field of dawa, because the influence of theatrical and cinematic arts is one of the most powerful influences in guiding the masses.

One of the greatest arts when the Arabs at the beginning, is singing and poetry, as taken by the Muslims and a means of preaching for the dissemination of Islam since early, like Hassan 
ibn Thabit, the Kaab bin Malik, and Abdullah bin Rawahah, and others suggesting that art commensurate with it age - in the call service, and this can be said that the arts should be taken as means of religious discourse, provided they are free of taboos[21].

We do not deny that Muslims are still reluctant to take the theater and cinema as a means of dawa as well as the scholars differed in its rule between prohibited and allowed, but it should be rational for a Muslim to be an expert on the people of his time, and who did not care about Muslims matters is not one of them. Art of theater and cinema, although have violations but have useful value of the programs, they are like books in which right and wrong, and books can not be left for some mistakes, as well as forms of art can not be left for some irregularities, but should be repealed these corrupt programs and stop sight and heard what the befitting heard and forbidden to look at it.

As long as Islam is attacked by the cinema, it was our duty confrontation with the same weapon, we even say that the cinema has become one of the necessities of religion, as by the enemies of Islam is trying to discredit Muslims in their faith and break up their unity and spoiling, it must to be a weapon to defend our religion and fight our enemies, war ahead of us is not by weapon but it is the intellectual invasion spread by the media. All this by taking into account its commitment controls legitimacy and tries to activate its functions in order to achieve its objectives and to prevent all that would contrary to Islamic values, that are not marked with the identity of the Muslim community[22].

Taking the theater and cinema as a means of dawa requires the need for regulatory body by the government to monitoring the proper application of Islamic values and spread them to reality. It is a kind of approach to the permanent evaluation and continuous review for each step towards the correct understanding of Islamic principles. The importance of supervision is thus evident through assessment, monitoring, and correction of procedures. Successful and useful films are well-managed and have effective control systems, which will enhance its ability to implement its strategy, taking into account Islamic values authentic[22].

Allah made Islam the law valid for every time and place, in which the wisdom and power of logic enable it to face and eliminate every problem, as well as alternatives that Allah enabled it through which that mimics the evolution and modernity in ways that elaborate practical, and then if we restrict the teachings of Islam within a closed bound and borders and remove it from its universality recipe, we stood helpless in front of this slope without being able to devise the better and useful for the nation and service worlds[23].

\section{Conclusion}

Through our modest presentation of this subject, we get that discourse in communication process in which the transfer of symbols of linguistic process by direct and indirect means, and in light of the amazing developments of information and communication technology that changed a lot of patterns dealing in life, it should be accompanied by the religious discourse of this digital revolution aspiration towards the transition to a digital society by introducing technology into its mechanisms and renovated modern means to raise the level of influence and persuasion, and most importantly taking the theatrical and cinematic arts as a means of dawa with the formation of a regulatory committee to follow up its programs service.

\section{References}

[1] A. al Baghdadi, Tajdid al Fikr al Diniy (Da'wah listikhdam al Aql), 3rd ed. Beirut: Arab Spread Foundation, 2008. 
[2] Muhammad 'Imarah, Mustaqbaluna Baina al Tajdid al Islamiy wa al Hadatsah al Arabiyah, 1st ed. Cairo: al Syuruq al Dawliyah Press, 2003.

[3] W. F. Jasim, al Khitab al Diniy wa al Wa'yu al Siyasiy fiy Mamlakah al Bahrain Tajadzub am Tanafur. Bahrain: Bahrain Institue for Political Development, 2015.

[4] I. A. A. H. Sami', Tajdid al Khitab al Diniy Bima Yatanasab Ma'a Ruh al Ashr (Dharurah Da'wiyah fiy Doi al Mustajaddat wa al Mutaghayyirat al Mu'ashirah), 1st ed. Beirut: Daar al-Kutub al-'Ilmiyah, 2004.

[5] J. Samiyah, "Mazhahir Tajdid al Khitab al Diniy wa Nataijuhu," in Tajdid al Khitab al Diniy Baina Diqqah al Fahm wa Tashih al Mafahim, 2016, p. 1418.

[6] M. B. al I. Abdullah, al Ittisal al Da'wiy Ususuhu al Ma'rifiyah wa Tathbiqatuhu al Manhajiyah, 1st ed. Oman: al Urdun Press, 2019.

[7] T. J. al 'Alwani, Ishlah al Fikr al Islamiy Madkhal Ila Nuzhm al Khitab fiy al Fikr al Islamiy al Mu'ashir, 5th ed. Beirut: World Institute of Islamic Thought, 2009.

[8] M. 'Imarah, Fiqh al Hadharah al Islamiyah, 1st ed. Cairo: Al Shorouk International Library, 2003.

[9] A. al Khuli, al Mujaddidun fiy al Islam, 1st ed. Cairo: Egyptian General Book Authority, 2003.

[10] Y. Muhammad, Jadaliyah al Khitab wa al Waqi', 2nd ed. Lubnan: Arab Spread Foundation, 2009.

[11] M. S. al Ma'rawi, "al Khitab al Islamiy al Mu'ashir Baina al Tajdid wa al Tabdid," in al Khitab al Islamiy al Mu'ashir Dakwah li al Taqwim wa I'adah al Nazhr, 1st ed., Doha: The Ministry of Awqaf for Islamic Affairs, 2006, p. 41.

[12] S. Grand and Clement, "Digital Learning: Education and Skills in The Digital Age," in Education and Skills, 2017, p. 1.

[13] A. M. Ruhumah, "Ilm al Ijtima" al Aliy. Kuwait: National Council for Culture, Arts and Letters, 2008.

[14] M. S. al K. al S. Idris and M. K. al D. Umar, "Atsar al Muhtawa al Raqamiy al Islamiy ala Mujtama' al Iftiradhiy," Majallah al Hijaz al Alamiyah al Muhakkamah li al Dirasat al Islam. wa al Arab., vol. 12, p. 336, 2015.

[15] R. Abud, al Muhtawa al Raqamiy al Arabiy ala al Internet Nazhrah ala al Istiratijiy al Arabiy wa al Alamiy, 1st ed. Cairo: al Arabiy li al Nasyri wa al Tawzi', 2013.

[16] H. Abud and M. al 'Ani, al I'lam wa al Hijrah ila al Ashr al Raqamiy, 1st ed. Oman: Hamid Press, 2015.

[17] A. al Hadi, “al 'Ulum al Syar'iyah wa Mu'thayat al Waqi' al Mu'ashir," in al Muktamar al Dauliy al Awwal: al Ulum al Syar'iyah Tahaddiyat al Waqi' wa Afaq al Mustaqbal, 2018, p. 767.

[18] M. A. B. al Sayyid, "Alaqat al Qanawat al Fadhaiyah al Diniyah bi Tajdid al Khitab al Diniy: Dirasah Nazhariyah Kaifiyah,” Majallah al Rai al Amm, vol. 16, no. 3, p. 15, 2017.

[19] H. Hubbullah, "Masyru'iyah Tajdid al Fikr al Diniy Hawajis wa Musawwigat," Tsaqafatuna li al Dirasat wa al buhuts, vol. 6, no. 22, p. 55, 2010.

[20] A. A. Sulaiman, "Muqtarahat 'Ilmiyah li Tajdid Aliyat al Khitab al Diniy wa Takwin al Du'at fiy Dhoi Khibrat wa Tajarib Ba'dhi al Muassasat al Hukumiyah wa al Dauliyah," in Bahst Tajdid Aliyat al Khitab al Diniy, 2015, p. 32.

[21] A. A. A. Rahman, Qadiyah Tahtwir al Khitab al Diniy: Tathwir al Dakwah ila al Islam, 1st ed. Cairo: al Wahbah Press, 2010.

[22] A. Z. Baharuddin, "Pengawasan Terhadap Acara Televisi Dalam Perspektif Fiqh Islami dan UU No. 32 Tahun 2002 Tentang Penyiaran Indonesia," Syarif Hidayatulla 
State Islamic University Jakarta, 2017.

[23] H. 'Isham al 'Akum, "Tawzif al Masrah fiy Khidmat al Da'wah al Islamiyah,” al Imam al Awza'i University, 2011. 